\title{
TTR
}

Traduction, terminologie, re?daction

\section{Polguère, Alain. Lexicologie et sémantique lexicale ; Notions fondamentales. Les Presses de l'Université de Montréal, collection Paramètres, Montréal, 2003, 260p.}

\section{Chantal Bouchard}

Volume 16, numéro 2, 2003

Traduction et (im)migration

Translation and (im)migration

URI : https://id.erudit.org/iderudit/010727ar

DOI : https://doi.org/10.7202/010727ar

Aller au sommaire du numéro

Éditeur(s)

Association canadienne de traductologie

ISSN

0835-8443 (imprimé)

1708-2188 (numérique)

Découvrir la revue

Citer ce compte rendu

Bouchard, C. (2003). Compte rendu de [Polguère, Alain. Lexicologie et sémantique lexicale; Notions fondamentales. Les Presses de l'Université de Montréal, collection Paramètres, Montréal, 2003, 260p.] TTR, 16(2), 264-265. https://doi.org/10.7202/010727ar d'utilisation que vous pouvez consulter en ligne.

https://apropos.erudit.org/fr/usagers/politique-dutilisation/ 
difficult for a computer to process. The authors, Eric Nyberg, Teruko Mitamura and Willem-Olaf Huijsen, pull specific examples from MT at Caterpillar Inc. to explain how controlled languages can bring about more favourable translation results. Chapter 15 titled Sublanguage by Harold Somers has a similar focus. Somers explains that sublanguage, a natural form of controlled language, appears in specific domains such as recipes, medicine and stock-market reports. To illustrate his argument he refers to Météo, the well-known Canadian MT system that has been successfully translating weather bulletins and reports for decades. The final chapter, titled Machine translation in the classroom again by Harold Somers, is the only article in the book devoted entirely to computers and translator training.

Although the title of the book is quite vague, Computers and Translation does an excellent job at exploring the most important aspects of translation technology without giving too much detail about any one system. It serves as an excellent resource to academics as well as translation and language professionals at large.

Sabine Lauffer

Glendon College, York University

\section{Polguère, Alain. Lexicologie et sémantique lexicale; Notions fondamentales. Les Presses de l'Université de Montréal, collection Paramètres, Montréal, 2003, 260p.}

L'ouvrage d'Alain Polguère est un manuel d'introduction à la lexicologie et à la sémantique lexicale. Comme l'indique le sous-titre notions fondamentales - son objectif est de présenter l'ensemble des notions utiles à l'étude du lexique. Remarquablement pédagogique dans son approche, l'auteur présente celles-ci de façon simple et claire en s'appuyant sur des exemples permettant de saisir immédiatement les définitions proposées. La progression d'un chapitre à l'autre est construite de façon à faciliter l'acquisition graduelle des outils d'analyse du sens lexical. À partir des notions de signe ( chapitre 2), puis de lexie ( chap. 3), on progresse donc à celles de structure du lexique ( chap. 5), de sens linguistique ( chap.6), pour aborder enfin les relations sémantiques lexicales ( chap. 7), l'analyse du sens (chap. 8) et les interférences paradigmatiques ( chapitre 9). L'ouvrage se clos sur un chapitre portant sur la lexicographie et les dictionnaires. Chaque 
chapitre présente une série d'exercices permettant d'approfondir les notions qui y sont abordées et une liste de textes de référence.

Même si l'auteur a cherché à éviter de se situer à l'intérieur d'une théorie linguistique en particulier, il trouve peu de pertinence à l'analyse sémique du type de celle de Bernard Pottier, qu'il expose rapidement au chapitre 8 , et reconnaît dans la conclusion de son ouvrage que la théorie Sens-Texte élaborée par Igor Mel'čuk constitue le cadre théorique le plus compatible avec les bases notionnelles qu'il présente dans cet ouvrage. Cela dit, l'approche est suffisamment ouverte pour que ce manuel puisse servir de base à l'enseignement des fondements de la lexicologie et de la sémantique lexicale, car il expose les notions qui font généralement consensus.

Solidement structuré et rédigé dans une langue claire, ce manuel s'avérera très bien adapté à l'enseignement au premier cycle universitaire dans tous les programmes où on s'intéresse aux questions de sémantique lexicale, en linguistique, bien sûr, mais aussi en terminologie et en traduction. C'est le meilleur ouvrage du genre depuis le Précis de lexicologie française de Jacqueline Picoche, qui date tout de même de près d'une trentaine d'années. Il serait utilement complété par un ouvrage sur la sémantique de la phrase que la conclusion semble d'ailleurs annoncer.

Chantal Bouchard Université McGill

Malingret, Laurence. Stratégies de traduction: les Lettres hispaniques en langue française. Arras Cedex, Artois Presses Université, 2002, 264p.

This volume presents the author's research on translations of Hispanic literature into French. Working firmly within the paradigm of Descriptive Translation Studies, Laurence Malingret seeks to reveal the processes of selection, interpretation and rewriting in a corpus of French translations of Hispanic literature for a period of 30 years (1950-1980) - all titles in the corpus are conveniently appendixed at the end of the book. The translations under review are drawn from French, Canadian, Belgian and Swiss bibliographies, though, not surprisingly, but significantly, most of the corpus is made up of French publications. The period chosen for analysis is particularly rich in that it represents a 